\title{
Examination of Foreign Language Classroom Anxiety and Achievement in Foreign Language in Turkish University Students in Terms of Various Variables ${ }^{1}$
}

\author{
Yunus Doğan ${ }^{1}$, Murat Tuncer ${ }^{2}$ \\ ${ }^{1}$ School of Foreign Languages, Frrat University, Turkey \\ ${ }^{2}$ Education Faculty, Frrat University, Turkey \\ Correspondence: Murat Tuncer, Education Faculty, Frrat University, Elazığ, 23119, Turkey
}

Received: January 26, 2016 Accepted: February 14, 2016 Online Published: February 16, 2016

doi:10.11114/jets.v4i5.1337

URL: http://dx.doi.org/10.11114/jets.v4i5.1337

\begin{abstract}
This correlational survey study aimed to investigate whether the Turkish prep-class students' foreign language classroom anxiety levels and foreign language achievement significantly differ in terms of such variables as their gender, their experience abroad, perceived level of income and any third language (other than Turkish and English) they knew. Moreover, the study also tried to identify whether the sub-dimensions of the foreign language classroom anxiety scalespeaking anxiety in language class, interest towards language class and anxiety of talking with native speakersignificantly differ in terms of the independent variables afore-mentioned. And the last aim of the study was to understand whether there is any significant correlation between the foreign language classroom anxiety and foreign language achievement. The participants of the study was consisted of 683 students who, having been registered to study at various engineering departments of Firat University, were receiving compulsory English preparatory education at the School of Foreign Languages during the academic year of 2013-2014. In order to measure the students' foreign language classroom anxiety, the scale developed by Horwitz, Horwitz\& Cope (1986) and adapted into Turkish by Gürsu (2011) was used. The grades of the students were taken from the School of Foreign Languages. For data analysis, such statistical tests as percentage, frequency, t-test, ANOVA, eta-squared and Pearson's Correlation were employed. As a result, it was understood that there is a negative correlation between foreign language classroom anxiety and foreign language achievement.
\end{abstract}

Keywords: Language Anxiety, Language Achievement, Gender, Economic status, Experience abroad

\section{Introduction}

One of the foremost goals of any national education system can be said to make individuals obtain knowledge and skills necessary for earning their own living, and to make them participate into labour force as employable people (Gürüz, 2008). The increasingly outstanding one of these target skills nowadays is the ability to communicate in a foreign language. In fact, in today's globalizing world, the widespread use of mass media, the internet in particular, and the ease of international travel have made intercultural communication more necessary than ever, and have in turn led to the phenomenal recognition of a 'lingua franca (Jenkins, 2009)'. In this context, one of the key competencies required in the labour force of the global knowledge economy is said to be the ability of oral and written communication in one's mother language and at least one foreign language, especially in English (Gürüz, 2008). However, the fact that teaching and learning foreign languages in Turkey have already turned out to be a problem is almost a finding shared by many researchers (Demirel, 1999, 2003; Iş̧1, 2008; Arslan, 2009; Haznedar, 2010; Bayraktaroğlu, 2012; Tosun, 2012).We think that one of the important obstacles in front of foreign language learning in our country is foreign language anxiety. In numerous researches carried out in Turkey (Demirdaş\&Bozdoğan, 2013; Aksoy, 2012; Demirdaş, 2012; Karaca, 2012; Öztürk, 2012; Burgucu, 2011; Karabey, 2011; Aydemir, 2011; Er, 2011; Sağlamel, 2009; Ergün, 2011; Balemir, 2009; Aydın, 2008; Sertçetin, 2006; Dalkılıç, 2001),it was identified that learners experience a remarkable and statistically significant level of anxiety in learning a foreign language. Regarded as a barrier in front of achievement in

\footnotetext{
${ }^{1}$ This study is taken from the first author's PHD dissertation
} 
foreign language learning (Aida, 1994; Arnold \& Brown, 1999; Horwitz, 2001), anxiety has almost unanimously been reported to be minimized in the relevant literature (Morreale, 2011; Huang, 2012).

Foreign language anxiety, a sophisticated unique structure involving learners' own beliefs, emotions and behaviours related to learning in foreign language classes (Horwitz, Horwitz and Cope, 1986; MacIntyre\& Gardner, 1991; Aida, 1994), is more often a speaking skill-oriented feeling of appraisal (Dewaele, 2007).In studies carried out on students (Horwitz et. al, 1986; MacIntyre\& Gardner, 1991; Campbell \& Ortiz, 1991;Onwuegbuzie et. al, 1999), foreign language classes have been reported to be the most anxiety-creating classes. It is understood from the relevant studies that the relationship between anxiety and academic achievement mostly displays a mutual structure. As learner's academic performance worsens, his/her level of anxiety related to any particular academic tasks increases (Huberty, 2009). Likewise, it is also known that an anxious learner will academically fail.

In many national and international research studies (Proulx, 1991; Aida, 1994; Horwitz, 2001; Demirdaş\&Bozdoğan, 2013; Demirdaş, 2012; Köroğlu, 2010; Gülözer, 2010; Kılıç, 2007; Batumlu, 2006; Gülsün, 1997; Kunt, 1997; Trylong, 1987; Saito et. al, 1999; Phillips, 1992; Ganschow et. al, 1994; Sparks et. al, 2000; von Wörde, 2003; Chan \& Wu, 2004; Hao et. al, 2004; Awan et. al, 2010; Wang, 2011), it is reported that there is a negative relationship between foreign language anxiety and achievement or proficiency in foreign language. On the other hand, some studies (Ehrman\& Oxford, 1995; Young, 1992; Horwitz, 1990; as cited in Brown, 2000) note down the benefit of facilitating anxiety in learning foreign languages. In Bailey (1983)'s study on competition and anxiety in foreign language learning, facilitating anxiety was said to be closely related to competition, and was one of the keys to success. And in the study in question, the positive effects of competition were explained with the facilitating anxiety structure (Brown, 2000). Sarıgül (2000) reports that there is no statistically significant relationship between these two variables. Such different findings, though the dimensions of the anxiety-achievement relationship are already known, have led to the need to research the boundaries of these dimensions more. Moreover, it is well-known that language learning is affected by cultural codes. Thus, even if the research problems may be similar, there could be different findings derived from the cultural codes, which makes it necessary to research the case more. In this study, we tried to investigate whether there is any correlation between the university students' foreign language anxiety and their achievement in foreign language learning, and whether these two dependent variables significantly differ in terms of such independent variables as gender, perceived economic status, experience abroad and any third language other than Turkish and English. What makes this research study unique and contributing to the literature is the fact that it focused on some variables such as experience abroad and the role of third language, which were observed not to have been studied in the Turkish context before.

\section{Method}

The research was conducted in the correlational survey method. The correlational survey models are research models aiming to determine the existence and /or level of covariance of two and more variables (Karasar, 2008). In the study, it was investigated whether there was any correlation between the university students', receiving English prep-class education, foreign language anxiety and their achievement in foreign language learning, and whether these two variables significantly differed in terms of such variables as gender, perceived economic status, experience abroad and any third language other than Turkish and English. It was further tried to reveal whether the sub-dimensions of the foreign language classroom anxiety scale- speaking anxiety in language class, interest towards language class and anxiety of talking with native speaker- significantly differed in terms of the independent variables afore-mentioned. And the study also tried to identify the relationships between the sub-dimensions of the foreign language anxiety and achievement in foreign language.

\section{Participants}

The participants of the study was consisted of 683 students who, having been registered to study at various engineering departments of Frat University, were receiving compulsory English preparatory education at the School of Foreign Languages during the academic year of 2013-2014. The univariate normality of the data was tested with certain statistical and graphical methods. P-P plot graphics and such statistical tests as kurtosis and skewness coefficients were evaluated. It was observed that these criteria were achieved. The independent variable characteristics of 683 students are given in Table 1. 
Table 1. Characteristics of the Research Participants

\begin{tabular}{llcc}
\hline & Groups & Frequency $(n=683)$ & Percentage (\%) \\
\hline \multirow{2}{*}{ Gender } & Female & 215 & 31.5 \\
\cline { 2 - 4 } & Male & 468 & 68.5 \\
\hline Experience-abroad & Yes & 64 & 9.4 \\
\cline { 2 - 4 } & No & 619 & 90.6 \\
\hline \multirow{2}{*}{ Perceived Economic Status } & Low & 58 & 8.5 \\
\cline { 2 - 4 } & Average & 587 & 85.9 \\
\cline { 2 - 4 } & High & 38 & 5.6 \\
\hline $\begin{array}{l}\text { Third language other than Turkish } \\
\text { and English }\end{array}$ & Yes & 183 & 26.8 \\
\cline { 2 - 4 } & No & 500 & 73.2 \\
\hline
\end{tabular}

It can be seen from Table 1 that $68.5 \%$ of the participants are male, $31.5 \%$ female, and $90.6 \%$ of them do not have experience abroad. Moreover, $85.9 \%$ of the participants perceive their economic status as middle. The $73.2 \%$ of the students do not know any third language other than Turkish and English.

\section{Data Collection}

For measuring the foreign language anxiety of the students, the Foreign Language Classroom Anxiety developed by Horwitz, Horwitz and Cope (1986) was used. The latest validity-reliability of the scale was understood to have been carried out by Gürsu (2011). As a result of the exploratory and confirmatory factor analyses of the scale, it was determined that the scale had a three-factor structure. These factors are "Speaking Anxiety in Language Class", "Interest towards Language Class", "and Anxiety of Talking with Native Speakers". A reliability test was conducted in the present study for the scale, and the Cronbach's Alpha coefficient was calculated as .751.

The students' foreign language achievement grades were collected from the School of Foreign Languages. The grades are the mean of what the students got from the Main Course, Grammar and Readingclasses in the first and second terms, and the mean score of the proficiency exam the students took at the end of the year. The general achievement grades of the students were determined by $60 \%$ of the tests, quizzes and exams of two terms, and $40 \%$ of the end-of-the-term proficiency exam. In order for a student to be successful at the compulsory English prep-class, he/she has to get at least 50 from the proficiency exam, and 70 as a general achievement grade.

For data analysis, such statistical tests as percentage, frequency, t-test, ANOVA, effect-size (eta-squared) and Pearson's Correlation were employed. For the interpretation of the effect sizes, the effect size rates cited by Büyüköztürk, Çokluk and Köklü (2012:189) from Green and Salkind (1997) were taken into account. These rates are at .01, .06 and .14 levels and as small, medium and large respectively.

\section{Findings}

The first investigation of the study was whether the foreign language classroom anxiety scale with its sub-dimensions and foreign language achievement significantly differed in terms of gender variable. The relevant findings are given in Table 2.

Table 2. Comparison of Foreign Language Anxiety Scale with its Sub-dimensions and Foreign Language Achievement in terms of Gender

\begin{tabular}{|c|c|c|c|c|c|c|c|c|}
\hline Variables & Gender & $\mathrm{N}$ & $\bar{X}$ & SD & $\mathrm{F}$ & $\mathrm{t}$ & $\mathrm{P}$ & $\eta^{2}$ \\
\hline \multirow{2}{*}{$\begin{array}{r}\begin{array}{r}\text { Foreign language } \\
\text { anxiety }\end{array} \\
\end{array}$} & Female & 215 & 3.00 & 0.41 & \multirow{2}{*}{1.035} & \multirow{2}{*}{-1.043} & \multirow{2}{*}{0.297} & \multirow{2}{*}{.002} \\
\hline & Male & 468 & 3.03 & 0.39 & & & & \\
\hline \multirow{2}{*}{$\begin{array}{r}\text { speaking anxiety in } \\
\text { language class }\end{array}$} & Female & 215 & 3.04 & 0.48 & \multirow{2}{*}{1.849} & \multirow{2}{*}{0.923} & \multirow{2}{*}{0.356} & \multirow{2}{*}{.001} \\
\hline & Male & 468 & 3.00 & 0.45 & & & & \\
\hline \multirow{2}{*}{$\begin{array}{r}\text { interest towards } \\
\text { language class } \\
\end{array}$} & Female & 215 & 2.48 & 0.62 & \multirow{2}{*}{10.311} & \multirow{2}{*}{-6.063} & \multirow{2}{*}{0.000} & \multirow{2}{*}{.045} \\
\hline & Male & 468 & 2.81 & 0.75 & & & & \\
\hline \multirow{2}{*}{$\begin{array}{r}\text { anxiety of talking } \\
\text { with native } \\
\text { speakers }\end{array}$} & Female & 215 & 3.27 & 0.75 & \multirow{2}{*}{4.282} & \multirow[b]{2}{*}{-2.570} & \multirow[b]{2}{*}{0.011} & \multirow[b]{2}{*}{.011 } \\
\hline & Male & 468 & 3.43 & 0.66 & & & & \\
\hline \multirow{2}{*}{ Achievement } & Female & 215 & 75.0 & 12.6 & \multirow{2}{*}{63.363} & \multirow{2}{*}{9.151} & \multirow{2}{*}{0.000} & \multirow{2}{*}{.080} \\
\hline & Male & 468 & 63.2 & 20.7 & & & & \\
\hline
\end{tabular}

According to Table2, there is statistically significant difference in the sub-dimensions "interest towards language class" $(\mathrm{t}(681)=-6.063, \mathrm{p}<.05))$ and "anxiety of talking with native speakers" $(\mathrm{t}(681)=-2.570, \mathrm{p}<.05))$ in favour of the male students, while in the foreign language achievement $(\mathrm{t}(681)=9.151, \mathrm{p}<.05))$ in favour of the female students. As to the effect sizes of gender, the rate is nearly medium in the "interest towards language class" sub-dimension, whereas the effect size rates for other dimensions are small.

The second independent variable of the study was the experience abroad of the participants. An independent-samples 
t-test was conducted in order to see whether there is any statistically significant difference in the foreign language anxiety scale with its sub-dimensions and achievement grades in terms of experience abroad variable. The relevant results are given in Table 3.

Table 3. Comparison of Foreign Language Anxiety Scale with its Sub-dimensions and Foreign Language Achievement in terms of Experience Abroad

\begin{tabular}{|c|c|c|c|c|c|c|c|c|}
\hline Variables & $\begin{array}{l}\text { Experience } \\
\text { abroad }\end{array}$ & $\mathrm{N}$ & $\bar{X}$ & SD & $\mathrm{F}$ & $\mathrm{t}$ & $\mathrm{P}$ & $\eta^{2}$ \\
\hline \multirow{2}{*}{$\begin{array}{r}\text { Foreign language } \\
\text { anxiety }\end{array}$} & Yes & 64 & 2.94 & 0.36 & \multirow{2}{*}{0.263} & \multirow{2}{*}{-1.727} & \multirow{2}{*}{0.085} & \multirow{2}{*}{.004} \\
\hline & No & 619 & 3.03 & 0.40 & & & & \\
\hline speaking anxiety & Yes & 64 & 2.91 & 0.44 & \multirow{2}{*}{0.004} & \multirow{2}{*}{-1.875} & \multirow{2}{*}{0.061} & \multirow{2}{*}{.005} \\
\hline in language class & No & 619 & 3.03 & 0.46 & & & & \\
\hline \multirow{2}{*}{$\begin{array}{r}\text { interest towards } \\
\text { language class }\end{array}$} & Yes & 64 & 2.66 & 0.77 & \multirow{2}{*}{0.041} & \multirow{2}{*}{-0.526} & \multirow{2}{*}{0.599} & \multirow{2}{*}{.000} \\
\hline & No & 619 & 2.71 & 0.72 & & & & \\
\hline \multirow{2}{*}{$\begin{array}{r}\text { anxiety of talking } \\
\text { with native } \\
\text { speakers } \\
\end{array}$} & Yes & 64 & 3.39 & 0.69 & \multirow{2}{*}{0.250} & \multirow[b]{2}{*}{0.102} & \multirow[b]{2}{*}{0.919} & \multirow[b]{2}{*}{.000} \\
\hline & No & 619 & 3.38 & 0.70 & & & & \\
\hline Achievement & $\begin{array}{l}\text { Yes } \\
\text { No }\end{array}$ & $\begin{array}{c}64 \\
619\end{array}$ & $\begin{array}{l}69.4 \\
66.7\end{array}$ & $\begin{array}{l}18.1 \\
19.4\end{array}$ & 1.251 & 1.053 & 0.293 & .002 \\
\hline
\end{tabular}

According to Table 3, no statistically significant difference was found in the foreign language anxiety scale and its sub-dimensions and the students' achievement in terms of the experience abroad variable ( $p>.05)$. And as for the effect-sizes calculated for this variable, it was observed that the experience abroad is not effective on the foreign language classroom anxiety and achievement.

The third independent variable of the study was perceived economic status. A one-way ANOVA test was carried out for this purpose, and the results are given in Table 4.

Table 4. Comparison of Foreign Language Anxiety Scale with its Sub-dimensions and Foreign Language Achievement in terms of Perceived Economic Status

\begin{tabular}{|c|c|c|c|c|c|c|c|c|}
\hline Variables & $\begin{array}{c}\text { Economic } \\
\text { status }\end{array}$ & $\bar{X}$ & $\mathrm{DF}$ & $\begin{array}{l}\text { Sum of } \\
\text { Squares }\end{array}$ & $\begin{array}{c}\text { Mean } \\
\text { Square }\end{array}$ & $\mathrm{F}$ & $\mathrm{P}$ & Diff \\
\hline Foreign & Low & 3.16 & 0.41 & 1.481 & 0.741 & \multirow{4}{*}{4.633} & \multirow{4}{*}{0.010} & \multirow{4}{*}{$\begin{array}{l}1-2 \\
2-3\end{array}$} \\
\hline language & Middle & 3.02 & 0.39 & 108.677 & 0.160 & & & \\
\hline anxiety & High & 2.92 & 0.41 & $\begin{array}{ll}\text { Total } & 110.158 \\
\end{array}$ & & & & \\
\hline \multicolumn{2}{|l|}{ Total } & 3.02 & 0.40 & Eta-Squared $\left(\eta^{2}\right) \therefore 013$ & & & & \\
\hline speaking & Low & 3.18 & 0.45 & $\begin{array}{ll}\text { B.G } & 2.791 \\
\end{array}$ & 1.396 & \multirow{4}{*}{6.537} & \multirow{4}{*}{0.002} & \multirow{8}{*}{$\begin{array}{l}1-2 \\
2-3\end{array}$} \\
\hline anxiety in & Middle & 3.01 & 0.46 & 145.174 & 0.213 & & & \\
\hline language class & High & 2.84 & 0.46 & $\begin{array}{ll}\text { Total } & 147.965 \\
\end{array}$ & & & & \\
\hline Total & & 3.02 & 0.46 & Eta-Squared $\left(\eta^{2}\right): .019$ & & & & \\
\hline interest & Low & 2.62 & 0.83 & B.G $\quad 0.968$ & 0.484 & \multirow{4}{*}{0.903} & \multirow{4}{*}{0.406} & \\
\hline towards & Middle & 2.71 & 0.73 & 364.706 & 0.536 & & & \\
\hline language class & High & 2.82 & 0.57 & Total $\quad 365.674$ & & & & \\
\hline \multicolumn{2}{|l|}{ Total } & 2.71 & 0.73 & Eta-Squared $\left(\eta^{2}\right): .003$ & & & & \\
\hline anxiety & Low & 3.52 & 0.79 & $\begin{array}{ll}\text { B.G } & 1.673 \\
\end{array}$ & 0.836 & \multirow{4}{*}{1.703} & \multirow{4}{*}{0.183} & \\
\hline talking with & Middle & 3.36 & 0.68 & 334.034 & 0.491 & & & \\
\hline native speakers & High & 3.45 & 0.76 & $\begin{array}{ll}\text { Total } & 335.707 \\
\end{array}$ & & & & \\
\hline \multicolumn{2}{|l|}{ Total } & 3.38 & 0.70 & Eta-Squared $\left(\eta^{2}\right) \therefore 005$ & & & & \\
\hline \multirow{4}{*}{ Achievement } & Low & 63.7 & 21.8 & $\begin{array}{cc}\text { B.G } & 696.8 \\
\end{array}$ & 348.4 & \multirow{4}{*}{0.928} & \multirow{4}{*}{0.396} & \\
\hline & Middle & 67.3 & 19.1 & 255332.1 & 375.4 & & & \\
\hline & High & 66.5 & 19.4 & $\begin{array}{ll}\text { Total } & 256028.9 \\
\end{array}$ & & & & \\
\hline & & 67.0 & 19.3 & Eta-Squared $\left(\eta^{2}\right) \therefore 003$ & & & & \\
\hline
\end{tabular}

According to Table4, there is statistically significant difference in the foreign language anxiety scale itself and in its "speaking anxiety in language class" dimension ( $<<.05)$.According to Tukey HSD test, the difference for both cases is between the low and the middle, and the middle and the high income groups. However, the effect-sizes in this respect are small, showing that perceived economic status is not very effective on foreign language anxiety and achievement.

The last independent variable of the study was whether the participants knew a third language other than Turkish and English. The relevant results are given in Table 5. 
Table 5.Comparison of Foreign Language Anxiety Scale with its Sub-dimensions and Foreign Language Achievement in terms of Third Language

\begin{tabular}{|c|c|c|c|c|c|c|c|c|}
\hline Variables & $\begin{array}{c}\text { Third } \\
\text { Language }\end{array}$ & $\mathrm{N}$ & $\bar{X}$ & df & $\mathrm{F}$ & $\mathrm{t}$ & $\mathrm{P}$ & $\eta^{2}$ \\
\hline \multirow{2}{*}{$\begin{array}{r}\text { Foreign language } \\
\text { anxiety }\end{array}$} & Yes & 183 & 3.01 & 0.41 & \multirow{2}{*}{2.125} & \multirow{2}{*}{-0.602} & \multirow{2}{*}{.547} & \multirow[t]{2}{*}{.001} \\
\hline & No & 500 & 3.03 & 0.39 & & & & \\
\hline \multirow{2}{*}{$\begin{array}{r}\text { speaking anxiety in } \\
\text { language class }\end{array}$} & Yes & 183 & 2.97 & 0.48 & \multirow{2}{*}{.878} & \multirow{2}{*}{-1.664} & \multirow{2}{*}{.097} & \multirow[t]{2}{*}{.004} \\
\hline & No & 500 & 3.03 & 0.45 & & & & \\
\hline \multirow{2}{*}{$\begin{array}{r}\text { interest towards } \\
\text { language class }\end{array}$} & Yes & 183 & 2.71 & 0.69 & \multirow{2}{*}{.939} & \multirow{2}{*}{-0.047} & \multirow{2}{*}{.963} & \multirow[t]{2}{*}{.000} \\
\hline & No & 500 & 2.71 & 0.74 & & & & \\
\hline \multirow{2}{*}{$\begin{array}{r}\text { anxiety of talking } \\
\text { with native speakers }\end{array}$} & Yes & 183 & 3.55 & 0.67 & \multirow{2}{*}{.946} & \multirow{2}{*}{3.950} & \multirow{2}{*}{.000} & \multirow[t]{2}{*}{.022} \\
\hline & No & 500 & 3.31 & 0.70 & & & & \\
\hline \multirow{2}{*}{ Achievement } & Yes & 183 & 66.0 & 20.2 & \multirow{2}{*}{1.763} & \multirow{2}{*}{-0.744} & \multirow{2}{*}{.457} & \multirow[t]{2}{*}{.001} \\
\hline & No & 500 & 67.3 & 19.0 & & & & \\
\hline
\end{tabular}

According to Table 5, there is a statistically significant difference only in the sub-dimension "Anxiety of Talking with Native Speakers" in favour of those who know a third language other than Turkish and English $(\mathrm{t}(681)=3.950, \mathrm{p}<.05)$. As to the effect-sizes in this sense, it is understood that knowing a third language is effective on the foreign language classroom anxiety and achievement at a small rate.

In order to understand the relationship between the foreign language classroom anxiety and its sub-dimensions and foreign language achievement, a correlation analysis was conducted, and the results are given in Table 6.

Table 6. The Correlation between Foreign Language Classroom Anxiety, its Sub-dimensions and Foreign Language Achievement

\begin{tabular}{|c|c|c|c|}
\hline Correlation & $\mathrm{N}$ & Pearson $(\mathrm{r})$ & $\mathrm{P}$ \\
\hline FLAA *FLCA & 683 & -.231 & $.000 * *$ \\
\hline FLAA * SALC & 683 & -.177 & $.000 * *$ \\
\hline FLAA * ITLC & 683 & -.389 & $.000 * *$ \\
\hline FLAA* ATNS & 683 & .052 & .173 \\
\hline FLCA* SALC & 683 & .951 & $.000 * *$ \\
\hline FLCA* ITLC & 683 & .408 & $.000 * *$ \\
\hline FLCA* ATNS & 683 & .371 & $.000 * *$ \\
\hline
\end{tabular}

FLCA: Foreign language classroom anxiety, SALC: Speaking Anxiety in Language Class, ATNS: Anxiety of Talking with Native Speakers, FLAA: Foreign Language Academic Achievement, ITLC: Interest towards Language Class

** Correlation is significant at .001

According to the results in Table 6, there are some negative (FLAA*FLCA, FLAA*SALC and FLAA * ITLC) and positive (FLCA* SALC, FLCA* ITLC and FLCA* ATNS) significant correlations ( $p<.001)$.

\section{Discussion}

This study aimed to investigate the foreign language classroom anxiety and achievement in foreign language of the Turkish university students who, having registered to various engineering departments, were receiving compulsory English prep-class education. The study also looked for whether there was any significant correlation between the students' foreign language classroom anxiety and their foreign language achievement. As a result of the study, it was understood that such sub-dimensions of the foreign language classroom anxiety scale as interest towards language class and anxiety of talking with native speakers, and foreign language achievement significantly differed in terms of gender variable. Some studies reporting no significant difference in this respect (Özdemir, 2013; Karabıyık, 2012; Özütürk \& Hürsen, 2012; Köroğlu, 2010; Doğan, 2008; Kılıç, 2007; Öner \& Gedikoğlu, 2007; Batumlu, 2006; Şakrak, 2009; Sarıgül, 2000; Shabani, 2012; Wang, 2011; Wang, 2010; French \& Richards, 1990) are available in the relevant literature. It was observed that the male students' level of interest towards language class and anxiety of talking with native speakers were higher than those of the females. Some studies reporting that male students are more anxious in learning a foreign language (Kitano, 2001; Nyikos, 1990; Karabey, 2011; Aydemir, 2011; Er, 2011) support this finding of the study. On the other hand, in Tuncer and Doğan (2015)'s study, it is reported that female students' level of interest towards language class is higher. It was further identified as a result that the students' foreign language achievement levels differed significantly in terms of gender. Accordingly, it was seen that the female students' academic achievement was higher than that of the males. The fact that females have stronger linguistic abilities, and that they are more successful than males at both mother tongue acquisition and foreign language learning is a highly admitted phenomenon in the relevant literature. In fact, Lutchmaya et. al (2002) emphasize that girls are more advantegeous, with a wider vocabulary, in terms of language abilities than boys. This fact has also been reported in various national studies (Deniz, Gülden \& Apaydın-Şen, 2013; Sarıcaoğlu \& Arıkan, 2009; Dursun, 2007). In Onwuegbuzie et. al (2000)'s study, it is 
stated that gender is one of the predictors of foreign language achievement, and that the females' level of achievement in foreign language learning is higher than that of the males.

As a result of the study, it was seen that the students' levels of foreign language anxiety and its sub-dimensions did not differ significantly in terms of experience abroad variable. Experience abroad is a cultural, touristic or educational short or long visit of a foreign language learner to any country where the target language is spoken. Such an experience has been told to provide foreign language learners with certain gains for language learning (Baro \& Serrano, 2011). Lafford (2006), in this respect, states that study-abroad contexts have traditionally been considered to be the best environments where a second language is learnt, and where its culture is best understood. It has been reported that experience-abroad improves language proficiency and adaptation to different cultures (Sato, 2014), provides significant changes in learners' analytical and experimental language learning beliefs and their self-efficacy/self-confidence levels (Tanaka \& Ellis, 2003), helps generate the willingness to communicate and interact with native speakers (Tsai, 2011), boosts second language learning motivation and helps learners develop their language learning approaches (Serrano, 2010). Furthermore, in Carroll (1967)'s preliminary study on 2,782 university students going abroad, it was reported that even a short-term experience abroad (for tours or for summer holidays) had a positive effect on foreign language proficiency (Lafford \& Collentine, 2006). Similarly, Llanes \& Munoz (2009)'s study also showed that even a 3-4 weeks of experience abroad produced important gains in all areas studied such as listening comprehension skill, and fluent and accurate speaking (Thompson \& Lee, 2014). And in Freed (1995)'s study on the students learning French as a foreign language, it was found that those having had a certain period of experience abroad France improved more in terms of verbal fluency than those who had not had this kind of an experience. Although it is reported in the relevant literature that the longevity of the time spent abroad provides many gains related to language learning (Davidson, 2010; Thompson \& Lee, 2014), it is also stated that experience abroad does not necessarily guarantee any improvement in the target language (Thompson \& Lee, 2014, Lafford \& Collentine, 2006). Campbell (2011) also reports that studying abroad is generally thought to offer an ideal environment for second language learning as opportunities of communicating with native speakers increase, however, recent studies emphasize that there is a disappointment in this sense since learners do not have enough interaction opportunities inside the classroom. Tuncer (2015), in a study on foreign students, draws attention to the fact that students who go abroad for education may be inclined to look for their own citizens in order not to experience a cultural shock, and states that this may lead to some motivational, environmental adjustment and learning problems. The result of the present study in this respect is important in the sense that an experience abroad does not necessarily provide any improvement in foreign language learning.

Another area in which the effect of experience abroad is investigated has been the foreign language anxiety of learners. Some studies in this sense (Allen \& Herron, 2003; Coleman, 1997; Morreale, 2011; Thompson \& Lee, 2014) touch upon the fact that experience abroad may reduce foreign language anxiety. Coleman (1997) claims that, after a certain period of experience abroad, learners are less afraid of making mistakes. Moreover, Thompson \& Lee (2014) note that experience abroad is effective on English class performance anxiety, confidence in speaking with English native speakers and on fear of ambiguity, and that experience abroad in the general sense reduces foreign language classroom anxiety. Segalowitzet.al (2004) concluded that learners having experience abroad are more relaxed while talking with native speakers. Furthermore, in Morreale (2011)'s study, those students having study abroad experience had more motivation and less anxiety. It was further identified as a result of the present study that the students' level of academic achievement did not differ significantly in terms of the experience abroad variable. A possible reason for this may be that the majority of the students were in the middle and low economic status groups and their experiences abroad, if any, may have probably been very short and for touristic purposes. For, we only asked the students whether they had been abroad before, but there were not any questions regarding their purpose or period of such experience, and they were not asked whether they had been to any country where the target language was spoken. In fact, Wright (1999) stresses the fact that having visited any country in which the language being learnt is spoken have a significant effect on the learners' language learning attitudes (Gayton, 2010).

It was determined as a result of the study that the students' levels of interest towards language class and anxiety of talking with native speakers and their academic achievement did not significantly differ in terms of their perceived economic status. However, the students' levels of foreign language anxiety and speaking anxiety in language class showed statistically significant difference in terms of their perceived economic status. Accordingly, the foreign language anxiety and anxiety of speaking in language class levels of those perceiving their economic status as low were higher than those from the middle and high economic groups. In this context, Ausubel (1968) thought that middle-class children are more academically competitive than their lower-class counterparts and demonstrate more ambition in their learning; and the parents in lower-class families encourage the aspirations of their children far less, because they do not give the same weight to education as middle-class parents do (Gayton, 2010). This idea supports the finding of this study that the students from the middle-class group did not show any significant failure or anxiety. However, as is 
understood from the findings, those perceiving themselves economically from low status were relatively more anxious. In the literature, in Çimen (2011) and Hanbay (2009)'s studies, the students' language attitudes did not differ in terms of their economic status; also in Çimen (2011)'s study, the students' anxiety levels showed no statistical difference in this respect. However, Alyaprak (2006) and Kayapınar (2006) found that the test anxiety levels of those children from the lower economic class were higher. And, Duman (2008) found that those children from the lower economic class had higher levels of trait anxiety, state anxiety and test anxiety (as cited in Çimen, 2011). Moreover, Ariani and Ghafournia (2015) concluded that learners' negative feelings toward foreign language learning can be related to their socio-economic status, and that socio-economic status can encourage or discourage learners. In Akramand Ghani (2013)'s study on Pakistani students, it was found that the students from the lower socio-economic status experienced more foreign language classroom anxiety than those from the higher status.

Another result of the study is that the students' levels of foreign language anxiety, anxiety of speaking in language class, interest towards language class and academic achievement did not show any statistically meaningful difference in terms of any third language they knew other than Turkish and English. However, the students' level of anxiety of talking with native speakers showed significant difference in terms of third language variable. Accordingly, the anxiety of talking with native speakers levels of those knowing a third language turned out to be higher than those who did not know any third language. As to multilingualism, Baker (2000) states that those who know three and four languages generally experience less anxiety in speaking in the second language, which is probably because their communicative skills must have improved as a result of exposure to other languages. Dewaele (2007) and Dewaele, Petrides and Furnham (2008) share similar results, and suggest that while foreign language anxiety and class anxiety related to second language learning are relatively high, the anxiety levels decrease with communication with more languages (as cited in Thompson \& Kkawaja, 2015). In the present study, the students were asked whether they knew any other language other than Turkish and English, however there were not any questions about the number of languages the students knew, or about whether these languages were their mother languages or not. It is probable that those who reported they knew a third language other than Turkish and English thought about one of the local languages (Kurdish, Zazaki, Arabic... etc.) which are not officially taught in Turkey. It is further possible that these students in question reported they knew such Western languages as German and French which are taught at some schools generally at elementary level in Turkey. In both cases, the students almost hardly have chances of studying or practicing these afore-mentioned languages other than Turkish, the only official language, and English, the most widespread foreign language in Turkey. In this case, it is quite normal that the anxiety levels of these students were found to be high. However, as put forward by Dewaele (2007) andDewaeleet.al (2008), the level of this relatively high anxiety of English is thought to decrease with more opportunities of communication in the languages the students reported they knew. Moreover, in Dewaele and MacIntyre (2014)'s study, it was found that "as the number of languages known by an individual increases, so does the enjoyment experienced in learning foreign languages; this heightened enjoyment decreases anxiety. Inversely, the fewer languages known, the more likely the individual is to experience less enjoyment and more anxiety" (as cited in Thompson \& Khawaja, 2015). Thompson and Khajawa (2015)'s study on foreign language anxiety and the role of bilingualism and multilingualism in Turkey showed that bilingual students experienced more English classroom anxiety, which partially supports the relevant finding of the present study. On the other hand, in the relevant literature, it is generally accepted that knowing any language means to be able to use that language fluently at least in daily occasions and especially communicative skills should be at a level not distrupting the flow and the structure of any communication (Common European Framework of Reference for Languages, 2001). There are nearly 36 ethnic minority languages in Turkey and all children, regardless of their first language, are to receive education in Turkish (Topbaş, 2011). We do not yet have any official data belonging to the first language proficiencies of these children. Therefore, it is thought that more in-depth research, especially in which both qualitative and quantitative methods are employed in a mixed approach, is necessary in order for us to have a clearer frame of reference in this sense.

The last but not least, important result of the study is that there is a statistically significant negative correlation between the students' foreign language classroom anxiety and their achievement in foreign language. This finding is encountered very often in the second language literature; in fact, since the preliminary study of Horwitz, Horwitz and Cope (1986) in this respect, many a study (Proulx, 1991; Aida, 1994; Horwitz, 2001; MacIntyre \& Gregersen, 2012; Huang, 2012; Hewitt \& Stefenson, 2011; Demirdaş\&Bozdoğan, 2013; Demirdaş, 2012; Köroğlu, 2010; Gülözer, 2010; Kılıç, 2007; Batumlu, 2006; Gülsün, 1997; Kunt, 1997; Trylong, 1987; Saito et. al, 1999; Phillips, 1992; Ganschowet. al, 1994; Sparks et. al, 2000; von Wörde, 2003; Chan \& Wu, 2004; Hao et. al, 2004; Awan et. al, 2010; Wang, 2011; MacIntyre\& Gardner, 1991; Young, 1991) have reported this finding. Gardner and MacIntyre (1993) suggest that anxiety is like motivation in theory; there is a connection between anxiety and students' level of proficiency, and at first phases of language learning, anxiety is generally at the utmost level, but decreases gradually with the increase of proficiency.

Together with all these findings, as also suggested in the relevant literature, it was understood that there are various 
relationships between anxiety and achievement in general, and foreign language anxiety and foreign language learning in particular. These results can be supported by the claim that there should be an anxiety measurement in terms of the validity and reliability of the measurement and evaluation activities to be carried out in the Turkish teaching/learning contexts. It was observed, with the effect sizes, that the independent variables of this study did not have that much significant effect on the dependent variables of the study. Thus, it is suggested that such variables as learning experiences, learning materials and motivation of the students be researched for their effects on this kind of anxiety of the students.

\section{References}

Aida, Y. (1994). Examination of Horwitz, Horwitz, and Cope's construct of foreign language anxiety: The case of $\begin{array}{llllll}\text { students of Japanese. Modern } & \text { Language }\end{array}$ http://dx.doi.org/10.1111/j.1540-4781.1994.tb02026.x

Akram, M., \& Ghani, M. (2013). The Relationship of Socioeconomic Status with Language Learning Motivation. International Journal of English and Education, 2(2), 406-413.

Aksoy, M. (2012). Yabancı Dil ÖğrenimindeKaygı, Utangaçlık, Strateji ve Akademik Başarı Arasındaki İlişki, Unpublished Doctoral Dissertation.Ankara University, Institude of Social Sciences.

Allen, H. W., \& Herron, C. (2003). A mixed-methodology investigation of the linguisticand affective outcomes of summer study abroad.Foreign Language Annals, 36, 385. http://dx.doi.org/10.1111/j.1944-9720.2003.tb02120.x

Ariani, M. G., \& .Ghafournia, N. (2015). The Relationship between Socioeconomic Status and Beliefs about Language Learning: A Study of Iranian Postgraduate EAP Students. English Language Teaching, 8(9), 17- 25. http://dx.doi.org/10.5539/elt.v8n9p17

Arnold, J., \& Brown, H. D. (1999). A map of the terrain.In J. Arnold (Ed.), Affect in Language Learning (pp. 1-24).Cambridge University Press.

Arslan, M. (2009). Türkiye'de Yabancı Dil Edinim Sorunu ve Yabancı Dil Olarak Türkçe.1st International Symposium on Sustainable Development, June 9-10, 2009, Sarajevo, Bosnia and Herzegovina.

Awan, R., Azher, M., Anwar, M., N., \&Naz, A. (2010). An investigation of foreign language classroom anxiety and its relationship with students' achievement. Journal of College Teaching and Learning, 7(11), 33-40.

Aydemir, O. (2011). A Study on the Changes In The Foreign Language Anxiety levels Experienced By The Students Of The Preparatory School At Gazi University During An Academic Year, Unpublished Master's Thesis, Gazi University, Institude of Educational Sciences.

Aydın, S. (2008). An investigation on the language anxiety and fear of negative evaluation among Turkish EFL learners.Asian EFL Journal, pp. 421-444.

Baker, C. (2000). A Parents' and Teachers' Guide to Bilingualism.Clevedon: Multilingual Matters.

Balemir, S. H. (2009). The Sources of Foreign Language Speaking Anxiety and The Relationship between Proficiency Levels and Degree of Foreign Language Speaking Anxiety, Unpublished Master's Thesis, Bilkent University, Institude of Educational Sciences.

Baro, A. L., \& Serrano, R. S. (2011). Length of Stay and Study Abroad: Language Gains in Two Versus Three Months Abroad. RESLA, 24, 95-110.

Batumlu, D. Z., \&Erden, M. (2007). The relationship between foreign language anxiety and English achievement of Yildiz Technical University School of Foreign Languages Preparatory students.Journal of Theory and Practicein Education, 3(1), 24-38.

Bayraktaroğlu, S. (2012a). Yabancı Dil Eğitimi Gerçeği, Yabancı Dille Eğitim Yanılgısı. Türkiye'de Yabancı Dil Eğitiminde Eğilim Ne Olmalı? Hacettepe Üniversitesi Eğitim Fakültesi Ingiliz Dili Eğitimi Anabilim Dalı 1.Yabancı Dil Eğitimi Çalıştayı Bildirileri 12-13 Kasım.

Bayraktaroğlu, S. (2012b). Neden Yabancı Dil Eğitiminde Başarılı Olamıyoruz? Türkiye'de Yabancı Dil Eğitiminde Eğilim Ne Olmalı? Hacettepe Üniversitesi Eğitim Fakültesi İngiliz Dili Eğitimi Anabilim Dalı 1.Yabancı Dil Eğitimi Çalıştayı Bildirileri 12-13 Kasım.

Brown, H. D. (2000). Principles of Language Learning and Teaching. Longman: New York.

Burgucu, A. (2011). The Role of Motivation, Attitude and Anxiety in Learning English as a Foreign Language. Unpublished Master's Thesis, KafkasUniversity, Institude of Social Sciences. 
Büyüköztürk, Ş., Çokluk, Ö., \& Köklü, N. (2012). Sosyal Bilimler için İstatistik. Pegem Akademi: Ankara.

Campbell, C. M., \& Ortiz, J. (1991). Helping students overcome foreign language anxiety: A foreign language anxiety workshop. E. K. Horwitz \& D. J. Young (Eds.), Language anxiety: From theory and research to classroomimplications. (pp. 141- 150). Englewood Cliffs, New Jersey: Prentice Hall.

Campbell, R. (2011). The impact of study abroad on Japanese language learners`social networks.New voices, The Japan Foundation, 5, 25-63.

Chan, D. Y. C., \& Wu, G. (2004). A Study of Foreign Language Anxiety of EFL Elementary School Students in Taipei County, Journal of National Taipei Teachers College, 17(2), 287-320.

Çimen, S. (2011). Ĕgitim fakültesi Öğrencilerinin İngilizceye Yönelik Tutum, İngilizce Kaygısl ve ÖzYeterlik Düzeylerinin Incelenmesi.Unpublished Master's Thesis, Karaelmas University, Institude of Social Sciences.

Coleman, J. (1997). Residence abroad within language study. Language Teaching, 30(1), 1-20. http://dx.doi.org/10.1017/S0261444800012659

Dalkılıç, N. (2001). An investigation into the role of anxiety in second language learning.Unpublished doctoral dissertation, The Institute of Social Sciences, Çukurova University, Adana, Turkey.

Demirdaş, Ö. (2012). Foreign Language Anxiety and Performance of Language Students in Turkish Unlversity Preparatory Classes, Unpublished Master'sThesis. Abant İzzet Baysal University, Institude of Educational Sciences.

Demirdaş, Ö., \&Bozdoğan, D. (2013). Foreign Language Anxiety and Performance of Language Learners in Preparatory Classes, Turkish Journal of Education, 2(3), 4-13.

Demirel, Ö. (1999). Yabancı dili öğrenemiyoruz. http://www.hurriyet.com.tr/egitim/anasayfa/6607825.asp?gid=171.

Demirel, Ö. (2003). Avrupa Birliği ve Dil Eğitimi. Türk Eğitim Sisteminde Yabancı Dil Eğitimi ve Kalite Arayışları Sетровуити, Özel Okullar Derneği.

Deniz, K. Z., Gülden, Ç., \& Apaydın-Şen, H. (2013). The Examination of Foreign Language Achievement in Terms of Certain Variables. İlköğretim Online, 12(2), 436-444.

Dewaele, J. M. (2007). the Effect of Multilingualism, Sociobiographical, and Situational Factors on Communicative Anxiety and Foreign Language Anxiety of Mature Language Learners. International Journal of Bilingualism, 11, 391-409. http://dx.doi.org/10.1177/13670069070110040301

Dewaele, J. M., Petrides, K. V., \& Furnham, A. (2008). Effects of trait emotional intelligence and sociobiographical variables on communicative anxiety and foreign language anxiety among multilinguals: A review and empirical investigation. Language and Learning, 59, 911-960. http://dx.doi.org/10.1111/j.1467-9922.2008.00482.x

Doğan, A. (2008). Lise öğrencilerinin ingilizce öğrenimlerini etkileyenyabancı dil kaygısı. Ankara ÜniversitesiDilDergisi, 139, 49-67.

Dursun, E. (2007). An Investigation into Reasons of Gender Differences in Foreign Language Learning Success at University Level Prep Classes. Unpublished Master's Thesis. Çanakkale OnSekiz Mart University Institude of Social Sciences.

Er, S. S. (2011). Anadolu Liselerine Devam Eden Öğrencilerin Yabancı Dil Başarılarında Yabancı Dile Yönelik Kaygı ve Inançlarının Etkisinin Incelenmesi, Unpublished Doctoral Dissertation. Ankara University Institude of Science.

Ergün, E. (2011). An Investigation into the Relationship between Emotional Intelligence Skills and Foreign Language Anxiety of Students at a Private Unıversity, Unpublished Master's Thesis. OrtaDoğuTeknikUniversity.

Freed, B. (1995). What makes us think that students who study abroad become fluent? In B. Freed (Ed.), Second language acquisition in a study abroad context (pp. 123-148). Philadelphia, PA: John Benjamins. http://dx.doi.org/10.1075/sibil.9.09fre

French, C., \& Richards, A. (1990). The Relationship between handedness, anxiety and questionnaire response patterns.British Journal of Psychology, 81, 57-62. http://dx.doi.org/10.1111/j.2044-8295.1990.tb02345.x

Ganschow, L., Sparks, R. L., Anderson, R., Javorsky, J., Skinner, S., \& Patton, J. (1994). Differences in language performance among high-, average-, and lowanxious college foreign language learners.The Modern Language Journal, 78(1), 41-55. http://dx.doi.org/10.1111/j.1540-4781.1994.tb02013.x

Gardner, R. C., \& McIntyre, P. D. (1993). On the measurement of affective variables in second language learning.Language Learning, 43, 157-194. http://dx.doi.org/10.1111/j.1467-1770.1992.tb00714.x 
Gayton, A. (2010). Socioeconomic Status and Language-Learning Motivation: to what extent does the former influence the latter? Scottish Languages Review, 22, 17-28.

Gülözer, A. (2010). Farklı Test Formatlarıile Ölçülen Yabancı Dil Başarısının; ÖğrencilerinTutumları, Kaygı Düzeyleri ve Öğrenme Stilleriile İlişkisinin İncelenmesi.Unpublished Master's Thesis. Abant İzzet Baysal University, Institude of Social Sciences.

Gülsün, R. (1997). An Analysis of the Relationship between Learners' Foreign Language Classroom Anxiety and Achievement in Learning English as a Foreign Language in the Freshman Classes at the University of Gaziantep, Unpublished Master's Thesis. Gaziantep University, Institude of SocialSciences.

Gürsu, F. (2011). The Turkish Equivalence, Validity, and Reliability Study of the Foreign Language Classroom Anxiety Scale, Unpublished Master's Thesis. YeditepeUniversity,Institude of Social Sciences.

Gürüz, K. (2008). Yirmi Birinci Yüzyllın Başında Türk Milli Eğitim Sistemi. Türkiye İş Bankası Kültür Yayınları: İstanbul.

Hanbay, O. (2009). 10. Sınıf öğrencilerinin farklı değiskenlere göre ikinci yabancı dil olarak almanca'ya yönelik tutumları. Elektronik Sosyal Bilimler Dergisi, 8(30).

Hao, M., Liu, M., \& Hao, R. (2004). An empirical study on anxiety and motivation in English as a foreign language.Asian Journal of English LanguageTeaching, 14, 89-104.

Haznedar, B. (2010). Türkiye'deYabancıDilEğitimi: Reformlar, YönelimlerveÖğretmenlerimiz. International Conference on New Trends in Education and Their Implications, 11-13 Kasım, Antalya.

Horwitz, E. K. (2001). Language Anxiety and Achievement.Annual Review of Applied Linguistics, 21, 112-126. http://dx.doi.org/10.1017/s0267190501000071

Horwitz, E. K., Horwitz, M. B., \& Cope, J. A. (1986). Foreign Language Classroom Anxiety.The Modern Language Journal, 70, 125-132. http://dx.doi.org/10.1111/j.1540-4781.1986.tb05256.x

Huang, J. (2012). Overcoming Foreign Language Classroom Anxiety. Nova Science Publishers, Inc.: New York.

Huberty, T. J. (2009). Test and performance anxiety.Principal Leadership, 10, 12-16.

Işık, A. (2008). Yabancı dil eğitimimizdeki yanlışlar nereden kaynaklanıyor? Journal of Language and Linguistic Studies, 4(2), 15-26.

Jenkins, J. (2009). English as a Lingua Franca: interpretations and attitudes. World Englishes, 28(2), 200-2007. http://dx.doi.org/10.1111/j.1467-971X.2009.01582.x

Karabey, M. (2011).Foreign Language Classroom Anxiety of Preparatory Class Students at Atatürk University, Unpublished Master's Thesis. Atatürk University Institude of Social Sciences.

Karabıyık, C. (2012). Foreın Language Anxiety: A Study AtUfuk University Preparatory School, Unpublished Master's Thesis. Gazi University Institude of Educational Sciences.

Karaca, M. (2012). Foreign Language Anxiety in Receptive Language Skills in ELT Classrooms at NecmettinErbakan University, Institude of Educational Sciences.Necmettin Erbakan University Institude of Educational Sciences

Karasar, N. (2008). BilimselAraştırmaYöntemleri. Ankara: Nobel YayınDağıtım.

Kılıç, M. (2007).The Sources and Relations of Foreign Language Listening Anxiety with Respect to Text Type and Learner Variables: A Case Study at Gazlantep Unıversity, Institude of Educational Sciences. Gaziantep University Institude of Social Sciences.

Kitano, K. (2001). Anxiety in the college Japanese language classroom.The Modern Language Journal, 85(4), 517-566. http://dx.doi.org/10.1111/0026-7902.00125

Köroğlu, H. (2010). Turkısh Elt Students' Readıng Anxiety and Their Strategies Use, Unpublished Master's Thesis. Kafkas University Institude of Social Sciences.

Kunt, N. (1997). Anxiety and beliefs about language learning: A study of Turkish-speaking university students learning English in North Cyprus. Applied Psycholinguistics, 20, 217-239.

Lafford, B. A. (2006). The Effects of Study Abroad vs. Classroom Contexts on Spanish SLA: Old Assumptions, New Insights and Future Research Directions. Selected Proceedings of the 7th Conference on the Acquisition of Spanish and Portuguese as First and Second Languages, ed. Carol A. Klee and Timothy L. Face, 1-25. Somerville, MA: Cascadilla Proceedings Project.

Lafford, B. A., \& Collentine, J. (2006). The Effects of Study Abroad and Classroom Contexts on the Acquisition of 
Spanish as a Second Language. R. Salaberry\& B.A. Lafford (eds.), The Art of Teaching Spanish: second language acquisition from research to praxis. Georgetown University Press: Washington, D.C.

Lutchmaya, S., Baron-Cohen, S., \& Raggatt, P. (2002). Foetal Testosterone and Vocabulary Size in 18-and-24-month-old Infants.Infant Behaviour and Development, 24, 418-424. http://dx.doi.org/10.1016/S0163-6383(02)00087-5

MacIntyre, P. D. \& Gardner, R. C. (1991). Methods and Results in the Study of Anxiety and Language Learning: A Review of the Literature. Language Learning, 41(1), 85-117. http://dx.doi.org/10.1111/j.1467-1770.1991.tb00677.x

Morreale, S. (2011). The Relationship between Study Abroad and Motivation, Attitude and Anxiety in University Students Learning a Foreign Language. Unpublished Doctorate Dissertation, Wayne State University, USA.

Nyikos, M. (1990). Sex Related Differences in Adult Language Learning: Socilization and Memory Factors. The Modern Language Journal Vol, 74-3, 273-286. http://dx.doi.org/10.1111/j.1540-4781.1990.tb01063.x

Öner, G., \& Gedikoğlu, T. (2007). Ortaöğretim Öğrencilerinin İngilizce Öğrenimlerini Etkileyen Yabancı Dil Kaygısı.Gaziantep Üniversitesi Sosyal Bilimler Dergisi, 6(2), 144-155.

Onwuegbuzie, A. J., Bailey, P., \& Daley, C. E. (2000). Cognitive, Affective, Personality, and Demographic Predictors of Foreign-LanguageAchievement.The Journal of Educational Research, 94(1), 3-15. http://dx.doi.org/10.1080/00220670009598738

Onwuegbuzie, A., Bailey, P., \& Daley, C. E. (1999). Factors associated with foreign language anxiety. Applied Socio Linguistics, 20, 218-239. http://dx.doi.org/10.1017/s0142716499002039

Özdemir, E. (2013). Türkçeyi Yabancı Dil Olarak Öğrenenlerin Konuşma Kaygılarının Kaynakları, YayınlanmamışYüksekLisansTezi. Gazi Üniversitesi Eğitim Bilimleri Enstitüsü, Ankara.

Öztürk, G. (2012). Forelgn Language Speaking Anxiety And Learner Motıvaton: A Case Study at a Turkish State University, Unpublished Master's Thesis.

Özütürk, G., \& Hürsen, Ç. (2012). Determination of English Language Learning Anxiety in EFL Classrooms.3rd World Conference on Psychology, Counselling and Guidance (WCPCG-2012), Procedia - Social and Behavioral Sciences, 84(2013), 1899-1907. http://dx.doi.org/10.1016/j.sbspro.2013.07.055

Phillips, E. M. (1992). The effects of language anxiety on students' oral test performance and attitudes.The Modern Language Journal, 76(1), 14-26. http://dx.doi.org/10.1111/j.1540-4781.1992.tb02573.x

Proulx, P. (1991). Anxiety in language learning: Recognition and prevention. Canadian Journal of Native Education, 18, 53-64.

Sağlamel, H. (2009). An Experimental Study on the Role of Creative Drama in Alleviating Language Anxiety in Speaking Classes with Reference to Teachers' and Learners' Perceptions of Language Anxiety, , Unpublished Master's Thesis. Karadeniz Teknik University Institude of Scial Sciences.

Saito, Y, Horwitz, E. K., \& Garza, T. J. (1999). Foreign language reading anxiety.Modern Language Journal, 83, 202-218.

Şakrak, G. (2009). The Relationship between Emotional Intelligence and Foreign Language Anxiety in Turkish EFL Students. UnpublishedMA Thesis, Bilkent University.

Sarıcaoğlu, A., \& Arıkan, A. (2009). ZekaTürleri, öğrencilerin yabancı dil başarıları ve seçilmiş değişkenler üzerine bir çalışma. EğitimdeKuramveUygulama, 5, 110-112.

Sarıül, H. (2000). Trait Anxiety or Foreign Language Anxiety and their Effects on Learners' Foreign Language Proficiency and Achievement.Unpublished Master's Thesis, BoğaziçiUniversityInstitude of Scial Sciences.

Sato, T. (2014). The Effects of Study Abroad on Second Language Identities and Language Learning.Turkish Online Journal of Qualitative Inquiry, July, 5(3).

Segalowitz, N., Freed, B., Collentine, J., Lafford, B., Lazar, N., \& Diaz-Campos, M. (2004). A Comparison of Spanish Second Language Acquisition in Two Different Learning Contexts: Study Abroad and the Domestic Classroom. Frontiers: The Interdisciplinary Journal of Study Abroad, 10, 1-18.

Serrano, S. L. (2010). Learning Languages in Study Abroad and at Home Contexts: A Critical Review of Comparative Studies. PortaLinguarum, 13, 149-163.

Sertçetin, A. (2006). Classroom Foreign Language Anxiety among Turkish Primary School Students.Unpublished 
Master's Thesis, UludağUniversity.

Shabani, M.B. (2012). Levels and Sources of Language Anxiety and Fear of Negative Evaluation among Iranian EFL Learners, Theory and Practice in Language Studies, 2(11), 2378-2383. http://dx.doi.org/10.4304/tpls.2.11.2378-2383

Sparks, R. J., Ganschow, L., \& Javorsky, J. (2000). Déjà vu all over again.A response to Saito, Horwitz, and Garza.The Modern Language Journal, 84(1), 251-255. http://dx.doi.org/10.1111/0026-7902.00066

Tanaka, K., \& Ellis, R. (2003). Study-abroad, Language Proficiency, and Learner Beliefs about Language Learning.JALT Journal, 25(1), 63-85.

Thompson, A. S., \& Lee, J. (2014). The Impact of Experience Abroad and Language Proficiency on Language Learning Anxiety.TESOL QUARTERLY, 48(2), 252-274. http://dx.doi.org/10.1002/tesq.125

Thompson, A. S., \&Khawaja, A. J. (2015). Foreign language anxiety in Turkey: the role of multilingualism. Journal of Multilingual and Multicultural Development. http://dx.doi.org/10.1080/01434632.2015.1031136

Topbaş, S. (2011). Implications of Bilingual Development for Specific Language Impairments in Turkey.Clinical Linguistics \& Phonetics, 25, 989-997. http://dx.doi.org/10.3109/02699206.2011.622425

Tosun, C. (2012). Yurdumuzda yabancı dil öğretme ve öğrenme sürecinde başarısızlığın nedeni yöntem mi? Hacettepe Üniversitesi Ĕgitim Fakültesi İngiliz Dili Eğitimi Anabilim Dalı 1.Yabancı Dil Eğitimi Çalıştayı Bildirileri 12-13 Kasım.

Trylong, V. L. (1987). Aptitude, Attitudes, and Anxiety: A Study of Their Relationships to Achievement in the Foreign Language Classroom, Unpublished Doctorate Dissertation, Purdue University, USA.

Tsai, Y. (2011). Exploring the Role of Motivation in the Reflection of the Effects of Intercultural Learning on Foreign Language Learning.International Journal of Humanities and Social Science Vol. 1 No. 15, Special Issue - Octobe

Tuncer, M. (2015). Yabancı öğrenci olgusu: Sayısal durum, sorunlar ve öneriler. Eğitime Bakış Dergisi, Yıl 11, Sayı 34, $51-55$

Tuncer, M., \& Doğan, Y. (2015). Effect of Foreign Language Classroom Anxiety on Turkish University Students' Academic Achievement in Foreign Language Learning.Journal of Education and Training Studies, 3(6), 14-19. http://dx.doi.org/10.11114/jets.v3i6.998

Von Worde, R. (1998). An investigation of students' perspectives on foreign language anxiety, Unpublished doctoral dissertation. George Mason University, Virginia.

Wang, J. R. (2011). Foreign Language Classroom Anxiety and English Academic Performance among Medical University Students in Taiwan, Unpublished Doctorate Dissertation. La Sierra University, the Faculty of School of Education.

Wang, T. (2010).Speaking Anxiety: More of a Function of Personality than Language Achievement. Chinese Journal of Applied Linguistics, 33(5), 95-109.

Young, D. J. (1991). Creating a Low-Anxiety Classroom Environment: What does Language Anxiety Research Suggest? The Modern Language Journal, 75(4), 426-439. http://dx.doi.org/10.1111/j.1540-4781.1991.tb05378.x

This work is licensed under a Creative Commons Attribution 3.0 License. 